\title{
The Effectiveness of Scirpus grossus and Limnocharis flava as Fitoremediation Agents of Nitrate-Phosphate to Prevent Microcystis Blooming in Fresh Water Ecosystem
}

\author{
Aliyah Siti Sundari, Catur Retnaningdyah*, Suharjono
}

Biology Departement, Faculty of Mathematics and Natural Sciences, Brawijaya University, Malang, Indonesia.

\begin{abstract}
The aim of this study was to reduce the concentration of dissolved nitrate-phosphate, because it can prevent the occurrence and inhibit the growth of Microcystis bloom waters. The study was conducted experimentally in the laboratory. The Microcystis isolation was carried out in Sutami Reservoir. Then, remediation treatment with hydromacrophyte (Scirpus grossus, Limnocharis flava and combination of both hydromicrophyte) were done during the 15 day incubation period. Abiotic factors were measured on day 0,6,12 and 15, but the abundance of Microcystis cells was counted daily. The productivity of hydromacrophyte was measured at the end of the research. The research results showed that hydromacrophytes were effective to reduce nitrate and phosphate concentrations. The combination of S. grossus and Microcystis reduced nitrate concentration up to $99.89 \%$, while the highest reduction of dissolved phosphate $(98.22 \%)$ was resulted from the combination of L. flava and Microcystis. The combination treatment of L. flava and S. grossus was capable to prevent Microcystis growth rate and produced the carying capacity of 65 cells.L-1.day- 1 and $6.93 \times 10^{4}$ cells $/ \mathrm{mL}$.
\end{abstract}

Keywords: bydromacrophyte, Microcystis, nitrate- phosphate reduction

\section{INTRODUCTION}

Aquatic ecosystem is an organism environment that is easy to be contamined. The decline of water quality is caused by pollutants from human activities such as residential trash, sedimentation, fertilizers and pesticides. The pollutans can cause euthropication which can be a triger of alga blooming. The alga blooming phenomenan is caused by the changes of concentration and imbalance nutrients ratio [1]. The differences of nitrat ratio and phospat can cause the growth of several types of algae, such as Microcystis, which tends to dominate. The statement is supported by research of Retnaningdyah et al [2] which shows that the groth of Microcystis is influenced by the level of nitrate in waters.

Microcystis is a kind of blue-green algae (Cyanobacteria) that generally grows on the surface of the water. At normal conditions,

\footnotetext{
${ }^{*}$ Corresponding author: Catur Retnaningdyah

Biology Department, Faculty of Mathematics and Natural

Sciences, Brawijaya University, Jl. Veteran, Malang,

Indonesia 65145

Email: catur@ub.ac.id
}

Microcystis is not harmful to other organism or humans. In certain conditions, such as high temperature of air with high nutrients (especially nitrate), Microcystis is able to grow rapidly that is commonly called as "algae blooms". The blooming conditions can cause Microcystis to produce toxins, called microcystin [3][4]. Microcystin has a high level of toxicity to both plants and animals, and can cause death [5].

Varoius efforts can be done to prevent the blooming Microcystis, either biologically, chemically, or mechanically. However, chemical and mechanical methods have a negative impact to the aquatic ecosystems; thus, it is necessary to develop biological methods to resolve the issue. One of them is to reduce the levels of nitrate through denitrification of waters emlpyoying the macrophyte, or is known as phytoremediation system. Phytoremediation is an attempt to use of plants and their parts to solve waste and other environmental pollution problems. Therefore the aim of the study was to solve the Microcystis blooming phenomenon by reducing the nitrate 
and phosphat level through bioremediation suppressing the growth and preventing the occurance of Microcystis blooming.

\section{MATERIALS AND METHODS}

The research was conducted from December 2011 to April 2012. The sample of Microcystis was taken from Sutami Reservoir, Malang, East Java. Hyromacrophyte and acquired land was taken from the wetland area around Malang, and the experiments were conducted in the Glasshouse Laboratory of Ecology and Animal Diversity and Microbiology Laboratory, Department of Biology, Faculty of Mathematics and Sciences, Brawijaya University, Malang.

\section{Isolation of Microcystis cell}

Microcystis samples were taken horizontally and parallel on the water surface of Sutami Reservoir, Malang, East Java, Indonesia using a one-litre-capacity water sampler. The water was then filtered using aplankton net to get Microcystis. Sample was then counted to obtain $5 \times 10^{8}$ cells. $\mathrm{mL}^{-1}$.

\section{Determination \\ Hydromacrophyte}

of

Potential

This study was an experiment study conducted using a complete randomized block design. The first factor was the type hydromacrophyte $(S$. grossus; $L$. flava; combination of $S$. grossus and $L$. flava, and without the addition hydromacrophyte). The second factor was with and without the addition of Microcystis. The system used for the experiments employed bacth culture in a tub and aquarium, with the addition of Sutami Reservoir water as much as $15 \mathrm{~L}$ for the tub and $5 \mathrm{~L}$ for the aquarium. The amount of soil added was as much as $20 \mathrm{~kg} /$ tub and $6 \mathrm{~kg} /$ aquarium. Water was enriched by phosphate $\left(\mathrm{K}_{2} \mathrm{HPO}_{4}\right) 0.4$ ppm.L-1 and nitrate $\left(\mathrm{NaNO}_{3}\right) 16$ ppm.L-1. The hydromacrophyte acclimatization was done in two weeks. After the acclimatization, the hydromacrohyte was added to the composition that had been modified according to the treatment (the addition of nitrate, phosphate, and Microcystis). The amount of each plant used was based on extensive research of plant closures by $25 \%$. Each treatment culture was then incubated in a glasshouse for 15 days.

\section{Measurement of Nitrate and Phosphate}

Abiotic factors observed in this study included the concentration of dissolved nitratephosphate which was measured in every five days. Nitrate concentrations were measured using brusin-colorimetric method. Dissolved phosphate concentrations were measured using stannous chloride-colorimetric method [6].

\section{Calculation of Abundance Microcystis}

The number of Microcystis cells was counted every day for 15 days to get the abundance sample of Microcystis. The sample was taken by filtering $100 \mathrm{~mL}$ of the treatment water using a plankton net having 406 pores per inch. Samples taken were boiled for 6 minutes, cooled and then counted for the number of cells using a $1 \times 10-4$ $\mathrm{cm} 3$ haemocytometer and binocular microscope at $400 \mathrm{x}$ magnification, and the density of Microcystis (cells $/ \mathrm{mL}$ ) was calculated using Formula 1 [7].

Cells number counted $\mathrm{x}$ volume concentration $(\mathrm{ml})$ $1 \times 10^{-4} \mathrm{~cm}^{3} \times$ volume filtered $(100 \mathrm{ml})$

\section{Data analysis}

Nitrate and phosphate concentrations on the treatment media were measured using ANOVA followed by a T-test on SPSS 16.00 for Windows. The data of Mycrocystis were used for calculating the rate of the individual growth. The calculation of the growth rate was done using Formula 2 [8].

$$
\mathrm{g}=\left(\ln \mathrm{N}_{\mathrm{t}}-\ln \mathrm{N}_{0}\right) / \mathrm{t}
$$

Note:

$\mathrm{g}:$ Value growth rate

Nt : The highest Microcystis population after incubation

N0: The initial number of Microcystis population

$\mathrm{t} \quad$ : The time required to achieve the highest Microcystis population

To find the difference of the growth rate $(\mathrm{g})$ and the maximum abundance of Microcystis (K) between treatments, ANOVA was conducted followed by Tuckey HSD test at the significance level of 5\% with SPSS 16.00 for Windows.

\section{RESULTS AND DISCUSSION}

Interaction between Microcystis, Scirpus grossus, and Limnocharis flava to reduce the concentration of Nitrate-Phosphate in the Media

The concentrations of nitrate and orthophosphate on all types of treatment media 
of hydromacrophyte decreased on the value of over $95 \%$. The result of concentration measurements of nitrate and ortophospate above $95 \%$ was shown on day $12^{\text {th }}$ and $15^{\text {th }}$ (Figure 1 and 2). Based on those pictures, it can be concluded that the decrease of the nitrate concentration and ortophosphate occured on treatment media with or without Microcystis addition.

Monoculture (S. grossus and L. flava) and polyculture treatment (combination of $S$. grossus and L. flava) showed significant results ( $\mathrm{p}>0.05)$ in decreasing the concentration of nitrate and orthophosphate in the media, this was indicated by the different notations (Figure 1 and 2). Decrease in nitrate concentration after fifteenday incubation showed a decrease in nitrate maximum concentration value from 0.04 to 0.09 $\mathrm{ppm} . \mathrm{L}^{-1}$. The decline in orthophosphate after fifteen-day incubation showed a maximum concentration of $0.01 \mathrm{ppm} . \mathrm{L}-1$. Thus, it was clear that virtually all of the plants were able to reduce nitrate and orthophosphate levels in aquatic media during the incubation period.
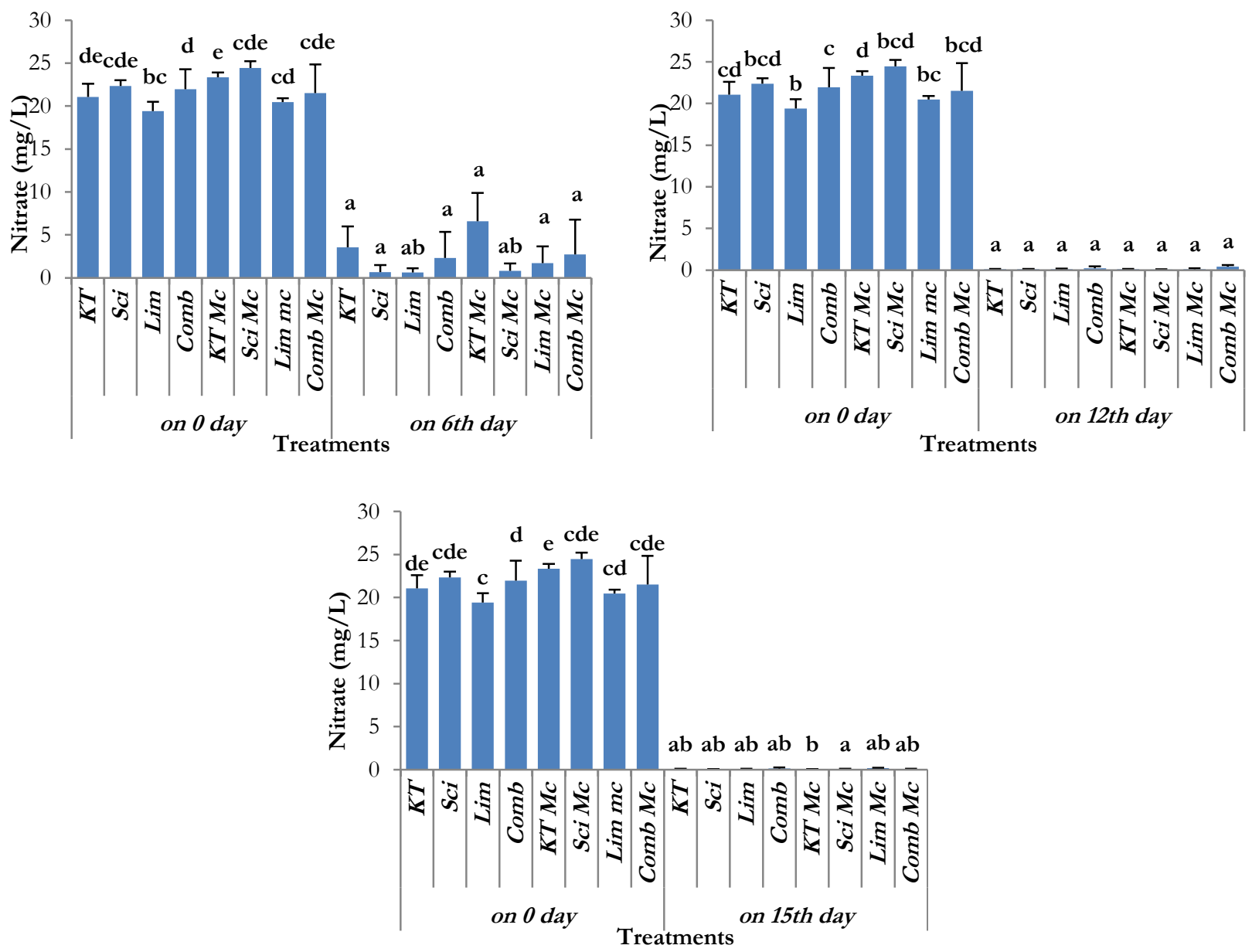

Figure 1. Comparison of nitrate concentration between day 0 and 6 (a), 0 and 12 (b), and 0 and 15 (c) after incubation. KT: control; Sci: S.grossus; Lim: L.flava; Comb: S. grossus-L. flava; KT Mc: control Microcystis; Sci Mc: S.grossus Microcystis; Lim Mc: L.flava Microcystis; Comb Mc: S. grossus-L. Flava Microcystis. The same notation show non significant difference based on ANOVA and T test

The decrease in concentration of nitrate and orthophosphate was used by hydromacrophyte as both a nutritional source of growth and a way of reducing bacteria interaction with organic compounds in the media. The bacteria couls be naturally derived from the soil and the water reservoir used as media. It is known that the ratio of the absorption of nutrients by the organisms between the nitrogen and phosphor is equal to $16: 1$, therefor when the phosphor content is high but is not supported by high levels of dissolved nitrogen, the phosphor can't be utilized for growing hydromacrophyte on media treatment [3].

Decrease in the concentration of nitrate and orthophosphate could also occur in the control group. The levels of nitrate and orthophosphate in the controls declined more than $90 \%$ on day 
12th. This was caused by the fact that the control media were also covered in algae of that genus (Cladophora and Phitophora). Both types of algae are parts of Cladophoraceae Family. Nitrate and orthophosphate can be utilized by hydromacrophyte and algae as a source of nutrients for growth. In general, algae can grow by utilizing the organic material in the media; and if there is no competition for nutrients with other plants of this type, then the algae can thrive.
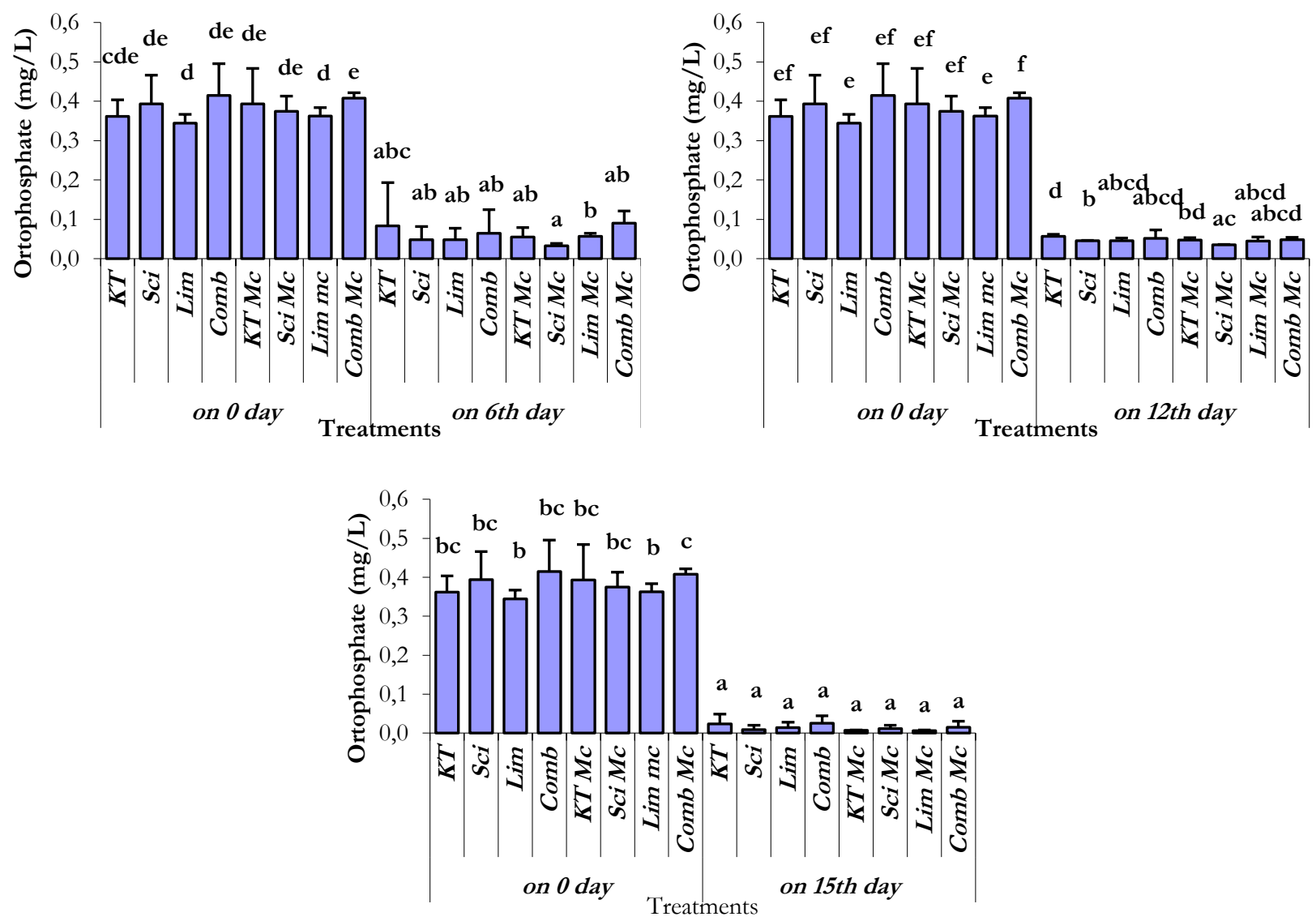

Figure 2. Comparison of Orthophosphate concentration between day 0 and 6 (a), 0 and 12 (b), and 0 and 15 (c) after incubation. KT: control; Sci: S.grossus; Lim: L.flava; Comb: S. grossus-L. flava; KT Mc: control Microcystis; Sci Mc: S.grossus Microcystis; Lim Mc: L.flava Microcystis; Comb Mc: S. grossus-L. Flava Microcystis. The same notation show non significant difference based on ANOVA and T test

Nitrogen is an essential element required for the synthesis of protein by animals and plants. Plants can't utilize nitrogen directly. With the help of microorganisms, nitrogen can be converted to other compounds such as ammonium, nitrate or other organic compounds. One of the function of nitrate utilization is as an agent for protein synthesis. The high concentration of nitrate in aquatic environment then can be utilized as a source of nutrients to produce new cells and colonies [9].

Phosphorus is a limiting factor for nutrients needed for the growth of hydromacrophyte and Microcystis. Media treatments added with soil can be used directly by hydromacrophyte mixed with nitrate and orthophosphate, so that their concentration could decrease every day. The phosporus element is an essential nutrient for the growth of organisms. In cell activity, elemental phosphor is needed to produce energy, making up nucleic acids and phospholipids of cell membranes [4].

\section{Growth response of Microcystis in the process of Phytoremediation}

The results of daily calculation of the number of Microcystis cells in the treatment and control media is shown in Figure 3. Based on the figure, it can be said that the growth of Microcystis was not trough a lag phase or an adaptation phase. Microcystis growth entered the exponential phase immediately, and was followed by the death phase. This happened on day 4 until day 5 of the observation when the maximum amount of 


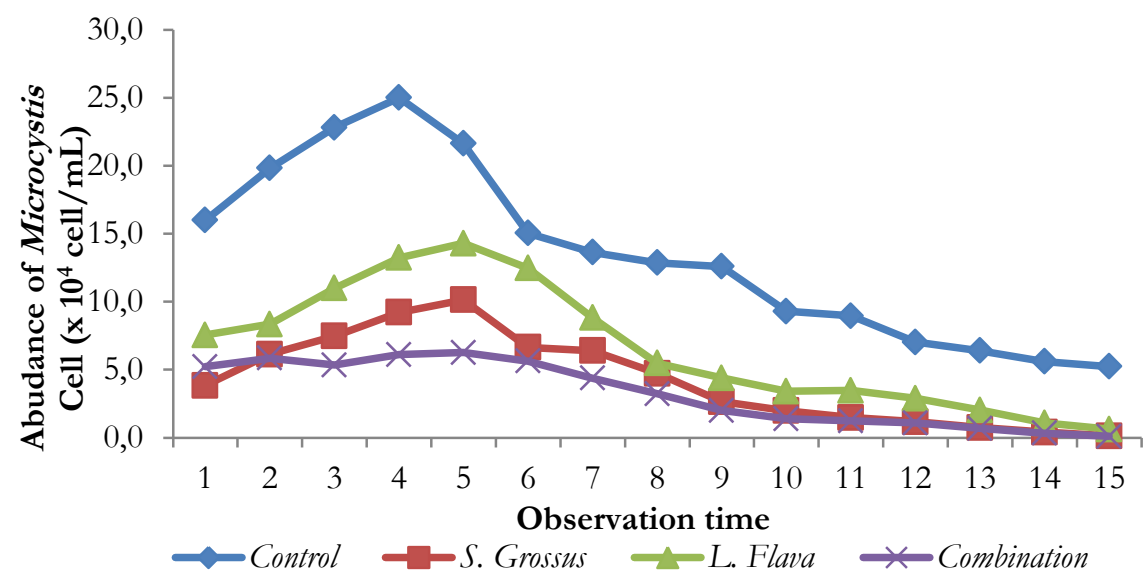

Figure 3. Growth pattern of Microcystis during observation.

growth of Microcystis could be supported by environmental resources.

Death phase is characterized by the declining number of Microcystis cells because nutrients started to run out. This was found during day 5 and 6 of the observation. The decrease in the nutrient content and in the capacity of available space could also affect the growth of Microcystis. The growth of Microcystis required high light intensity and nutrients. The death of Microcyst was caused by the lack of nutrients in the media and accumulation of toxic, which caused the media to be not conducive for growth. Furthermore, the numbers of dead Microcysti cells could be influenced by nutrient conditions, environment condition, as well as types of microorganisms.

All hydromacrophyte had same potential in reducing the abundance of Microcystis, but the ability of each plant to grow was different in lower abundance. The results showed that a

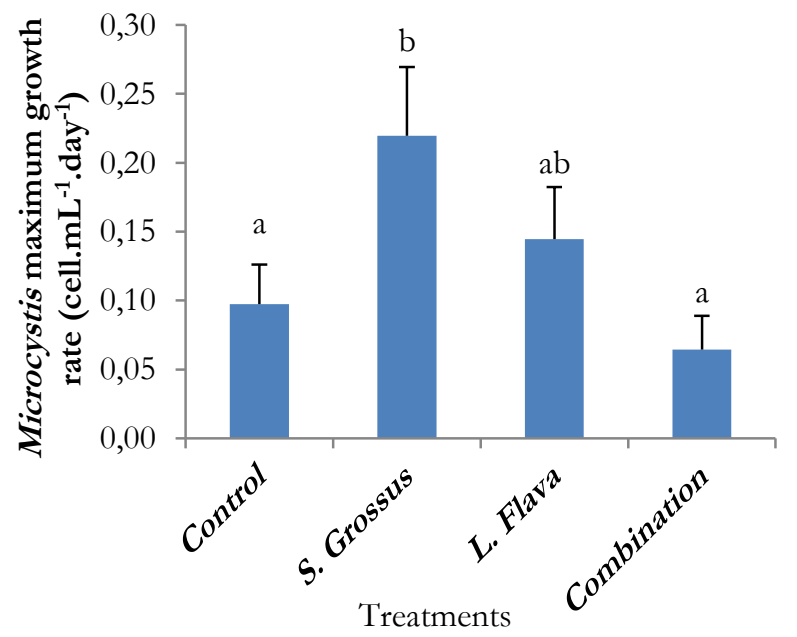

combination treatment of $S$. grossus and $L$. flavasignificantly inhibited the growth of Microcystis until $72 \%$ after six days of incubation. The other treatments had lower effect than the combination treatment.

\section{Growth rate and maximum abundance of Microcystis cells}

The growth rate and carrying capacity of Microcystis in the treatment and control media could be determined by the value of cell density. Based on statistical analysis, it was known that $\mathrm{K}$ and $g$ value were significantly different $(\mathrm{p}>0.05)$ between control media and $\mathrm{K}$ and $\mathrm{g}$ value of the hydromacrophyte treatment (Figure 4a). The highest growth rate of Microcystis was for the treatment media of $S$. grossus and the lowest value of Microcystis growth rate was found in the combination treatment of $S$. grossus and L. flava.

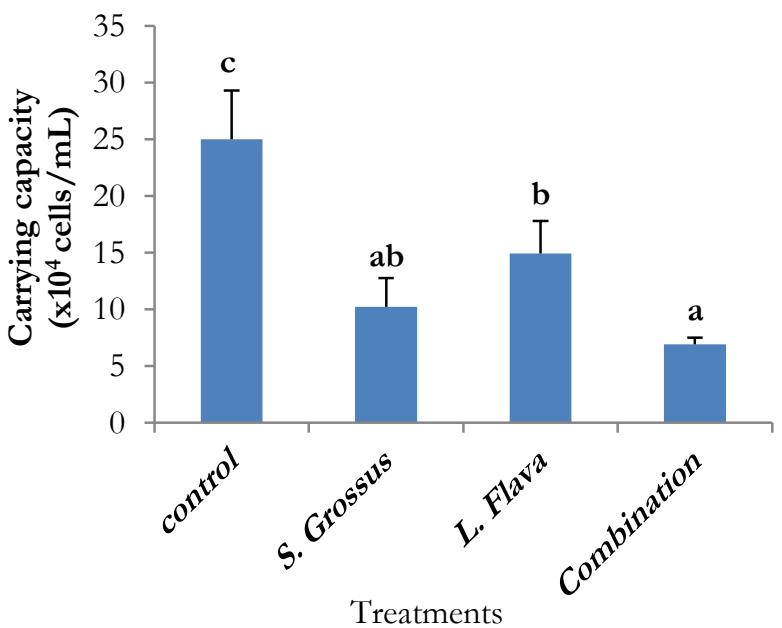

Figure 4. Maximum growth rate (a) and carrying capacity of Microcystis during observation (b). Notes: The same notation show non significant difference based on ANOVA and T test 
The result of the carrying capacity in each treatment which showed that the highest abundance of Microcystis was related to the environmental conditions presented in the control treatment, and was equal to $25 \times 10^{4}$ cells $/ \mathrm{mL}$, while the lowest abundance of Microcystis presented in the combination treatment of $6.93 \times 104$ cells $/ \mathrm{mL}$. The control treatment showed a high carrying capacity because of the absence of competition to obtain nutrients. Directly, Microcystis contained in the media resource control could utilize $\mathrm{N}$ and $\mathrm{P}$, although it was noted that the media controls were also covered by other types of algae which was Cladophora and Phitophora.

Overall, the combination treatment could inhibit the growth of Microcystis due to the competition for nutrients. The lowest value growth rate and the lowest carrying capacity of Microcystis was found in treatment combination of $S$. grossus and L. flava. This could be due to competition in the acquisition of nutrients by hydromacrophyte. In addition, the canopy structure of S. grossus and L. flava also caused Microcystis to unable to grow because the light was blocked by the canopy of the plants.

\section{CONCLUSION}

The results showed that all hydromacrophyte (S. grossus and L. flava) had similar potential to reduce the nitrate and orthophosphate level until $90 \%$ after six-day incubation. Hydromicrophyte was also able to prevent Microcystis blooming in the fresh water ecosystem. The carrying capacity of Microcystis $25 \times 10^{4}$ decreased up to $6.93 \times 104$ cells/mL after six-day incubation or it can be said that the carrying capacity of Microcystis decreased up to $72 \%$ after six-day of incubation.

\section{ACKNOWLEDGEMENTS}

The research was supported by the General Directorate of Higher Education (DIKTI), Ministry of National Education. Thanks is also addressed to myfriendsin the research team.

\section{REFERENCES}

1. Carpenter, SR (2008) Phosphorus control is critical to mitigating eutrophication.Proceedings of the National Academy of Sciences.105(32):11039-11040.

2. Retnaningdyah C, Suharjono, Soegianto A, Irawan B, (2010) Daya dukung dan laju pertumbuhanMicrocystishasil isolasi dari waduk sutami pada berbagai variasi konsentrasi nitrat dan fosfat dalam medium selektif B-12. Biota. 15(3): 354-362.

3. Oberholster PJ, Botha G (2004) Microcystis spp. source of toxic microcystin in drinking water. Africa Journal Biotechnology. 3(3): 159-168.

4. Romanowska-Duda Z, Mankiewicz J, Tarczynska M, Walter Z, Zalewski M (2002) The effect of toxic cyanobacteria (blue green algae) on water plants and animal cells. Polish J. of Environmental Studies. 11(5): 561-566.

5. Samino S, Retnaningdyah C (2006) Monitoring dinamika komunitas fitoplankton dan zooplankton di waduk sutami malang periode bulan oktober sampai desember 2004. Research Report Cooperation Jasa Tirta I with the Department of Biology Faculty of Mathematics and Science Certificate No.ID03/0127 UB.

6. Clesceri LS, Arnold EG, Trussel RR, Mory AHF (1998) Standart method for the examination of water and waste water $20^{\text {th }}$ Ed. American Public Health Association. Washington.

7. Joung SH, Kim CJ, Ahn CY, Jang KY, Boo SM\&Oh $\operatorname{HM}(2006)$ Simple method for a cell count of the colonial cyanobacteriumMicrocystis sp. The Journal of Mocrobiology. 44 (5): 562565.

8. Davis ML, Masten SJ (2004) Principle of enviromental engineering and science Mc. GrawHill Companies Inc. New York.

9. Ramirez JJ, Bicudo CEM (2005) Diurnal and spatial (vertical) dynamics of nutrient $(\mathrm{N}, \mathrm{P}, \mathrm{Si})$ in four sampling days (summer, fall, winter and spring) in a tropical shallow reservoir and their relationship with the phytoplankton community. Brazil Journal Biology. 65(1): 141-157. 